\title{
Movie as A Medium to Create an Equal Society
}

\author{
Wening Jiwandaru Pradanri ${ }^{1^{*}}$ \\ ${ }^{1}$ Department of Communication Sciences, Faculty of Social and Political Science, Diponegoro University.
}

\begin{abstract}
Kartini movie may not succeed commercially, but it had 34 nominations and won 3 awards from 3 different film festivals. These different perspectives allowing variety tendencies of active audience reception. In prior researches, shows that Indonesia still facing a gender inequality in the fields of education. This study aims provides overview of the four active audiences reception on Kartini movie, in order to be a medium that creating an equal society using qualitative approach and constructivism paradigm. This study concluded that there are tendencies of dominant meanings acceptance in Kartini movie. All of the four subjects felt that it delivered such powerful messages about creating an equal society. They agreed that the messages delivered in three main scenes of the movie. The first scene is when Kartini persuade her sisters to free their souls and minds by reading books. The second scene is when Kartini was told by a moslem leaders, that both of men and women must have equal opportunities to a proper education. The last scene is when Kartini giving terms and conditions to a man who proposed her to be his wives, it successfully giving a proper education to women and children in needs.
\end{abstract}

Keywords: Reception Analysis, Kartini, Movie

\section{Introduction}

As Indonesian national hero, Kartini figures is such an inspiring role as pioneer of education for Indonesian girls and women's rights. Her story adapted to a film and suddenly became one of the most awaited movie in early 2017, but it was before the social media viral controversies of Dian Sastrowardoyo who plays Kartini in the film. A video recorded her arrogant response to her fans, suddenly Indonesian social media users took actions by boycotting Kartini movie. It affecting Kartini movie commercially for only had 509.982 viewers, compares to Danur a local horror movie which had 2.736.107 viewers in the same month screenings.[1]

In the other hands, Kartini movie had 15 nominations on Piala Maya Award, 14 nominations on Indonesian Film Festival and 5 nominations on Bandung Film Festival. In those 3 different film awards, Kartini always won The Best Supporting Actress nomination. All of the nominations and awards, proved that Kartini may not succeed commercially but still delivers such powerful messages on gender equality in education and women's rights. These different perspectives, allowing variety tendencies of audience reception. Nowadays, audience becoming more active and giving various reception that is not always exactly the same as expected by the directors of the movie.

Previous research by Rahmi Fitrianti and Habibullah shows that there is a gender inequality in the fields of education on Majalaya District, Karawang, West Java, Indonesia. It influenced by the value in a society, which forms a negative stereotype that causes women marginalization, sub-ordination, and over-load work. That is why this study important to be implemented and aiming to provides overview of the active audience reception on Kartini movie in order to be a medium that creating an equal society, especially on gender equality in the fields of education.

\section{Methodology}

The paradigm used is constructivist paradigm. Constructivism sees truth as something very subjective and created by participants but is the reality of all that has been formed by the process of history and the social, cultural and political economic forces. In the research process, the researcher acts as one of the participants[2]. This research uses qualitative approach, research subject is four men who already watched Kartini movie. Selecting men as subjects of this study, to provides overview their subjective experiences as active audience while having reception on Kartini movie. Methods of data collection are in-depth interviews and observations. This study uses Reception Theory by Stuart Hall, which places attribution and meaning constructions taken from the media by the recipient. Receptive theories classify an active audience in interpreting the meaning of mass media messages into several categories, namely preferred, negotiated, and oppositional. The analytical method used in this study is descriptive analysis method. The first data analysis phase is open coding, the second

\footnotetext{
* Corresponding author: wening29@gmail.com
} 
stage is axial coding, and the last one is selective coding[3].

\section{Discussion}

All four of this study subjects already watched Kartini movie. The third and fourth subjects declare a rejection that the whole film is about women's right and gender equality in the fields of education. Both of them thought that the whole film is almost about how Javanese ethnic society, should always fulfilled the tradition and cultural etiquette of Java. According to both of their perspectives, this film illustrates that not only women but also the entire society of ethnic Java, have to fulfilled those traditions and manners.

The first and second subjects have an exact reception like the way that directors of the movie expected. Both of them thought that the whole film is about how Kartini lead and empowering women's right and gender equality in the field of education. Especially, for the poor and low class of society. But in the end, all of the four subjects felt that Kartini movie delivered such powerful messages about create an equal society in Javanese tradition. Especially, about women's right and gender equality in the field of education.

All of the four subjects having the same reception about those powerful messages, they agreed that the messages delivered in three main scenes of the movie. The first scene is when Kartini told both of his sisters that their bodies can be locked in a room, to uphold the tradition of Javanese ethnics named "pingitan". But, their souls and minds must fly freely. Pingitan tradition forced Kartini and two of her sisters to stay in their room since the first day of menstruation, until someone proposed them to be their wives. In this scene, Kartini persuade two of her sisters to free their souls and minds by reading books as many as they can.

The second scene is when Kartini by her own will try to making a conversation with Kiyai, a moslem leaders. She asked the Kiyai is there any verses in Al-Quran, The Moslem Bible, which explained that a moslem should having a proper education. The Kiyai told Kartini that it is "Iqro", where The Almighty God commands every mankind to read, and both of men or women must have equal opportunities to a proper education.

The third and last scene is when Kartini giving terms and conditions to a man who proposed her to be his wives. By giving requirements, Kartini were the first women to breaking boundaries of Javanese ethnics to not letting a man freely propose someone to be his wives. One of Kartini's conditions that she asked to her future husband, are he have to hand in hand with her by building school for the poor and low class of the society. This school have a purpose to giving a proper education for everyone in needs. All of the four subjects agreed that these scenes contain valuable message about women's right and gender equality in the field of education.

\section{Conclusion}

This study concluded that there are tendencies of dominant meanings acceptance in Kartini movie. All of the four subjects felt that Kartini movie delivered such powerful messages about creating an equal society, especially on women's right and gender equality in the fields of education. They agreed that the messages delivered in three main scenes of the movie. Which is when Kartini persuade two of her sisters to free their souls and minds by reading books as many as they can, the second scene is when Kartini was told by Kiyai, a moslem leaders, that both of men and women must have equal opportunities to a proper education. The last scene is when Kartini giving terms and conditions to a man who proposed her to be his wives, it was not only breaking boundaries of Javanese ethnics. But also, one of Kartini's conditions successfully giving a proper education to women and children in needs. Moreover, this movie can increase public awareness about daily life which can brings positive impacts to other things like environment, social, economy, and etc.

As the recommendations, reception analysis can be done not only to overview the audience reception of media content, but researchers also can determine the role of media to certain needs.

\section{References}

1. Brilio, Film Kartini Cuma mendapat sedikit Penonton, Ini Kata Hanung Bramantyo, Retrieved from https://www.brilio.net/film/film-kartini-cumadapat-sedikit-penonton-ini-kata-hanung-bramantyo170425l.html at September 11, 2017 (2017).

2. N. Lawrence, Social Research Methods: Qualitative and Quantitave Approaches, Ally and Bacon, Boston (2003).

3. O. Rettria, Analisis Resepsi Audiens Terhadap Personal Branding Raditya Dika dalam RVLOG (Raditya Video Log) di YouTube Channel Raditya Dika, Thesis of Gajah Mada University, p.20-24 (2017). 